\title{
Comparative Studies between Rates of Incorporation of Branched-Chain Amino Acids and Their $\alpha$-Ketoanalogues into Rat Tissue Proteins under Different Dietary Conditions
}

\author{
S. HAUSCHILDT and K. BRAND \\ Institute of Physiological Chemistry, University of \\ Erlangen-Nuremberg, Fahrstraße 17, 8520 Erlangen, \\ Federal Republic of Germany
}

(Received June 14, 1983)

\begin{abstract}
Summary Male albino rats (110-120g) were fed for 10 days on an amino acid diet low in nitrogen (nitrogen $=1.05 \%$ ) devoid of valine, leucine and isoleucine and supplemented with branched-chain $\alpha$-ketoacids $(9.4 \%$ ) (BCKA-diet). Pair-fed controls received an isocaloric diet (AAdiet) which contained the three branched-chain amino acids $(1.4 \%)$ instead of the $\alpha$-ketoacids (nitrogen $=1.2 \%$ ). A third group was fed on a standard diet. Measuring rates of incorporation of radioactive leucine, valine and their corresponding $\alpha$-ketoacids into liver, kidney, heart and brain proteins of rats fed on a standard diet revealed that in liver, branched-chain $\alpha$ ketoacids are incorporated to a lesser extent than the corresponding amino acids. The same was also observed with the BCKA-diet, while the AA-diet reduced $\mathrm{BCAA}$ incorporation with the consecutive improvement of the relative incorporation of BCKA over that of BCAA.

Injection of branched-chain amino- and $\alpha$-ketoacids results in equal rates of incorporation in kidney and heart proteins. Injecting branched-chain $\alpha$ ketoacids leads to higher incorporation rates in brain than injecting branched-chain amino acids. Thus rates of incorporation of branchedchain $\alpha$-ketoacids differ dependent on the tissue and on the diet applied. They are not consistent with those of branched-chain amino acids.

Key Words branched-chain $\alpha$-ketoacids, amino acid incorporation, protein, rat tissues, dietary nitrogen
\end{abstract}

Several authors have shown that in mammals the $\alpha$-ketoanalogues of methionine, phenylalanine and the branched-chain amino acids are transaminated to the corresponding amino acids and thus used for protein synthesis (1-7).

Amination of the ketoacids should lead to a fall in the body pool of total nitrogen and to diminished ureagenesis.

This rationale underlies the application of the $\alpha$-ketoanalogues in the treatment 
of diseases accompanied by elevated nitrogen and urea levels, such as renal failure, hepatic insufficiency and urea cycle enzyme defects $(8,9,10)$.

The administration of $\alpha$-ketoanalogues for therapeutic use emphasizes the need for more information concerning the metabolic fate of branched-chain $\alpha$-ketoacids (BCKA) when applied to the intact organism.

Since it would seem important to establish the role of transamination of BCKA and the capability of different organs to use BCKA as protein precursors in vivo, we decided to inject $\left[1-{ }^{14} \mathrm{C}\right]$-labeled $\mathrm{BCKA}$ into rats and measure the amount of radioactivity that was incorporated into different tissue proteins.

In order to evaluate the significance of $\mathrm{BCKA}$ as protein precursors relative to $\mathrm{BCAA}$, incorporation rates were compared with those obtained after the injection of $\left[1-{ }^{14} \mathrm{C}\right]$-labeled BCAA.

Additional experiments were undertaken to determine whether dietary BCKA influence transamination of BCKA and subsequent incorporation into tissue proteins.

\section{MATERIALS AND METHODS}

Animal and diets. Male Sprague Dawley rats (Jvanovas, Kisslegg, FRG) initially weighing $80 \mathrm{~g}$ were housed in individual cages in a room with controlled humidity and temperature $\left(23^{\circ} \mathrm{C}\right)$ and with a fixed 12 -h artificial light-dark cycle. Water was provided ad libitum. Upon arrival the animals had free access to a powdered standard diet. Having reached a weight of $110-120 \mathrm{~g}$, the rats were divided into three groups, each group consisting of 30 animals. Group 1 was fed on a $9.4 \%(65.1 \mathrm{mmol} / 100 \mathrm{~g}$ diet $)$ BCKA diet which contained instead of valine, leucine and isoleucine the corresponding $\alpha$-ketoanalogues in amounts equivalent to three times the minimal daily requirement (MDR) (11) of the branched-chain amino acids (Ca-salts of BCKA were a generous gift from the Company Pfrimmer, Erlangen, FRG). The $\alpha$-ketoanalogues of valine, leucine and isoleucine were added in amounts (mmol/100 g diet) of 21, 25.4 and 18.7 respectively. The amino acid and nitrogen contents of the diet were $7.58 \mathrm{~g}$ and $1.02 \mathrm{~g} / 100 \mathrm{~g}$ diet respectively. The amino acids included (g/1,000 g diet): L-lysine, 9.257; L-methionine, 4.115; Lcysteine, 1.8; L-phenylalanine, 5.915; L-tyrosine, 1.8; L-arginine, 6.943; L-histidine, 2.315; L-tryptophan, 0.771; L-threonine, 2.725; DL-alanine, 1.8; L-asparagine, 3.085; L-aspartic acid, 1.8; L-glutamic acid, 18; glycine, 11.983; L-proline, 1.8, and DL-serine, 1.8. Group 2 was fed on an isocaloric amino acid diet (AA) (Altromin, Laage, FRG) (nitrogen $=1.2 \%$ ). This diet contained the same amino acid mixture as described for the BCKA-diet, except that the branched-chain amino acids L-leucine $(5.657 \mathrm{~g})$, valine $(4.217 \mathrm{~g})$ and $\mathrm{L}$-isoleucine $(4.217 \mathrm{~g})$ were added so that the diet contained $9 \mathrm{~g}$ amino acids per $100 \mathrm{~g}$ diet. The BCAA content was $11.1 \mathrm{mmol} / 100 \mathrm{~g}$ diet. The amount of food available to group 2 was restricted to the amount of food group 1 had eaten the previous day. The composition of the two diets has been described in detail previously(12). Weight and food consumption of the animals 
were measured daily. Group 3, the control group, received a standard diet (Altromin diet 1324, Laage, FRG) containing 25\% protein, $5.6 \%$ fat and $68.9 \%$ carbohydrates. No synthetic amino acids were added. The experiments lasted for 10 days.

Incorporation of radioactive amino acids into proteins. On the morning of the 10th day, six animals from each group, all being in the fed state, were injected intraperitoneally with one of the following compounds: $\left[1-{ }^{14} \mathrm{C}\right]$ leucine, [1$\left.{ }^{14} \mathrm{C}\right]$ valine, $\left[1-{ }^{14} \mathrm{C}\right] \alpha$-ketoisocaproate $\left(\alpha\right.$-KIC), $\left[1-{ }^{14} \mathrm{C}\right] \alpha$-ketoisovalerate $(\alpha-\mathrm{KIV})$ and $\left[U-{ }^{14} \mathrm{C}\right] \mathrm{lysine}$. The amount injected provided per $100 \mathrm{~g}$ body weight $14.0 \pm 0.2 \mu \mathrm{mol}$ $(0.5 \mu \mathrm{Ci} / \mu \mathrm{mol})$ of the amino- and $\alpha$-ketoacids and $0.400 \pm 0.008 \mu \mathrm{mol}(10 \mu \mathrm{Ci} /$ $\mu \mathrm{mol})$ of lysine. Fifteen min after injection the animals were killed under ether anesthesia, blood was collected and deproteinized with 5-sulfosalicylic acid $(5 \mathrm{mg} / \mathrm{ml})$ and the individual tissues were quickly removed, weighed and frozen in liquid nitrogen. Tissues were ground to fine powder with a mortar and pestle chilled with liquid nitrogen. The powder was homogenized with 5 volumes of $0.01 \mathrm{M}$ triethanolamine-hydrochloride buffer $\mathrm{pH} 7.6$ and $2 \mathrm{ml}$ of the homogenate was precipitated with $2 \mathrm{ml}$ of $10 \%$ trichloroacetic acid $(\mathrm{w} / \mathrm{v})$. The precipitate was washed three times with $2 \mathrm{ml}$ of $5 \%$ trichloroacetic acid (w/v). After washing a final time with $2 \mathrm{ml}$ of ethanol-triethanolamine-hydrochloride buffer $(3: 1)$ the pellets were dried, resuspended in $2 \mathrm{ml}$ hyamine, heated for $20 \mathrm{~min}$ at $60^{\circ} \mathrm{C}$ and an aliquot was placed in a counting vial containing $10 \mathrm{ml}$ Bray solution. The samples were counted in a Packard scintillation spectrometer. In pilot studies it was shown that incorporation of radioactivity was linear with time up to $15 \mathrm{~min}$.

Determination of specific radioactivity of leucine. Trichloroacetic acid was removed from the supernatants of the homogenates by diethyl ether extraction. In the supernatants of homogenates and of plasma, the specific radioactivity of leucine was determined on an automated amino acid analyzer fitted with a pump for dividing the effluent from the column (Biotronic LC 6000). The specific radioactivity of protein-bound leucine was determined similarly after extensive washing of the precipitate followed by hydrolysis in $6 \mathrm{~N} \mathrm{HCl}$ at $110^{\circ} \mathrm{C}$ for $24 \mathrm{~h}$.

Amino acid analysis. Amino acids were analyzed in the supernatant of plasma and homogenate and in liver protein hydrolysates on a Biotronic automatic amino acid analyzer LC 6000 E. Supernatants and hydrolysates were obtained as described above.

Materials. Radioactive compounds were purchased from Amersham Buchler $\mathrm{KG}$; Braunschweig, FRG. $\left[1-{ }^{14} \mathrm{C}\right] \alpha$-Ketoisocaproate and $\left[1-{ }^{14} \mathrm{C}\right] \alpha$-ketoisovalerate were prepared from the corresponding $\left[1-{ }^{14} \mathrm{C}\right]$-labeled amino acids leucine and valine by deamination with snake venom L-amino acid oxidase according to the method described by Meister (13). Purification was achieved by combined cation and anion-exchanges chromatography on tandem columns $(1 \times 10 \mathrm{~cm})$ each containing Lewatit S 1080 (70-150 mesh) in $\mathrm{H}^{+}$form and Lewatit $\mathrm{M} 5080$ (100-200 mesh) in the acetate form. Protein was determined according to Bensadoun and Weinstein (14). 
Statistical calculations were done by two factorial analyses of variance. Paired comparisons were carried out according to Scheffé (15).

\section{RESULTS}

Table 1 shows the effect of the experimental diets on daily weight gain and food intake. The intake of $9.4 \mathrm{~g}$ of the BCKA-diet results in a daily weight gain of $1.7 \mathrm{~g}$ which is equivalent to growth rates observed in the pair-fed AA group. The diets were fed for 10 days before incorporation studies were carried out.

Injecting rats fed on the standard diet with a dose of $\left[1-{ }^{14} \mathrm{C}\right]$ leucine ( $14 \mu \mathrm{mol} / 100 \mathrm{~g}$ body $\mathrm{wt}$ ) leads to an incorporation of $5.3 \%$ of the injected dose into liver proteins (Table 2). The rate of incorporation is reduced to $3.5 \%$ when $\left[1-{ }^{14} \mathrm{C}\right] \alpha-$ ketoisocaproate is administered. Similar differences are observed after the adminis-

Table 1. Body weight gain and food intake of rats fed branched-chain $\alpha$-ketoacids.*

\begin{tabular}{lcc}
\hline Dietary treatment & $\begin{array}{c}\text { Weight gain } \\
\text { (g/day) }\end{array}$ & $\begin{array}{c}\text { Food intake } \\
\text { (g/day per 100g body wt.) }\end{array}$ \\
\hline Standard diet & $5.3 \pm 1.8$ & $16.2 \pm 4.7$ \\
BCKA & $1.7 \pm 0.8$ & $9.4 \pm 1.9$ \\
AA & $1.8 \pm 0.7$ & $9.1 \pm 2.0$ \\
\hline
\end{tabular}

*Values are means $\pm \mathrm{SD}, n=24$.

Table 2. Effect of dietary treatment on incorporation of radioactive amino acids and their corresponding $\alpha$-ketoanalogues in rat liver and brain proteins.*

\begin{tabular}{|c|c|c|c|}
\hline $\begin{array}{l}\text { Compound } \\
\text { injected }\end{array}$ & Standard diet & $\begin{array}{c}\text { BCKA } \\
(\% \text { of injected dose/organ })\end{array}$ & AA \\
\hline \multicolumn{4}{|c|}{ Liver } \\
\hline$\left[1-{ }^{14} \mathrm{C}\right]$ Leu & $5.31 \pm 0.14^{\mathrm{a}, \mathrm{c}}$ & $5.79 \pm 0.76^{\mathrm{b}, \mathrm{d}}$ & $2.76 \pm 0.19^{\mathrm{a}, \mathrm{b}}$ \\
\hline$\left[1-{ }^{14} \mathrm{C}\right] \alpha-\mathrm{KIC}$ & $3.50 \pm 0.15^{\mathrm{c}}$ & $3.18 \pm 0.26^{\mathrm{d}}$ & $2.73 \pm 0.21$ \\
\hline$\left[1-{ }^{14} \mathrm{C}\right] \mathrm{Val}$ & $4.74 \pm 0.14^{\mathrm{e}}$ & $4.26 \pm 0.71^{\mathrm{f}}$ & $3.26 \pm 0.62$ \\
\hline$\left[1-{ }^{14} \mathrm{C}\right] \alpha-\mathrm{KIV}$ & $1.84 \pm 0.26^{\mathrm{e}}$ & $1.86 \pm 0.29^{\mathrm{f}}$ & $2.34 \pm 0.34$ \\
\hline$\left[U_{-}{ }^{14} \mathrm{C}\right]$ Lys & $3.83 \pm 0.29$ & $2.88 \pm 0.21$ & $2.93 \pm 0.19$ \\
\hline \multicolumn{4}{|c|}{ Brain } \\
\hline$\left[1-{ }^{14} \mathrm{C}\right] \mathrm{Leu}$ & $0.110 \pm 0.003^{\mathrm{g}}$ & $0.154 \pm 0.015^{\mathrm{h}}$ & $0.143 \pm 0.013^{\mathrm{i}}$ \\
\hline$\left[1-{ }^{14} \mathrm{C}\right] \alpha-\mathrm{KIC}$ & $0.151 \pm 0.006^{\mathrm{g}}$ & $0.223 \pm 0.011^{\mathrm{h}}$ & $0.242 \pm 0.025^{\mathrm{i}}$ \\
\hline$\left[1-{ }^{14} \mathrm{C}\right] \mathrm{Val}$ & $0.101 \pm 0.010^{\mathrm{j}}$ & $0.132 \pm 0.020^{\mathrm{k}}$ & $0.128 \pm 0.020^{1}$ \\
\hline$\left[1-{ }^{14} \mathrm{C}\right] \alpha-\mathrm{KIV}$ & $0.203 \pm 0.010^{\mathrm{j}}$ & $0.262 \pm 0.030^{\mathrm{k}}$ & $0.277 \pm 0.020^{1}$ \\
\hline
\end{tabular}

* Values are expressed as means of per cent of the injected dose per whole organ \pm SEM, $n=5-10$. Means having common superscript letters are significantly different $(p<0.05)$. 
tration of $\left[1-{ }^{14} \mathrm{C}\right]$ valine and $\left[1-{ }^{14} \mathrm{C}\right] \alpha$-ketoisovalerate.

When feeding the AA-diet instead of the standard diet, rates of incorporation of radioactivity from leucine and valine into liver proteins decrease. This decrease was not observed after intake of the BCKA-diet (Table 2, column 2).

The failure to show a decrease in incorporation rates cannot be explained by differences in liver weights, since in both experimental groups liver weights were about the same (Table 3).

To test whether injection of amino acids other than those that are absent from the BCKA-diet also results in elevated incorporation rates, $\left[U_{-}{ }^{14} \mathrm{C}\right]$ lysine was injected and rates of incorporation into liver protein were measured. The results are shown in Table 2.

Independent of the experimental diets, $2.9 \%$ of the injected dose of $0.4 \mu \mathrm{mol}$ $\left[U_{-}{ }^{14} \mathrm{C}\right]$ lysine $(10 \mu \mathrm{Ci} / \mu \mathrm{mol})$ per $100 \mathrm{~g}$ rat was incorporated into liver proteins, $23 \%$ less than after feeding the standard diet.

To further clarify the reason for the observed increased amino acid incorporation rates in livers of BCKA-fed rats, leucine concentrations were measured in plasma and liver (Table 4), and after injection of $\left[1-{ }^{14} \mathrm{C}\right]$ leucine, determinations of specific radioactivity of leucine in plasma, in the acid soluble supernatant of liver homogenate and in liver proteins, were carried out. The results are given in Table 5.

Compared to the standard diet, specific radioactivity increases in plasma and decreases in protein after dietary treatment with the amino acid diet (AA).

Table 3. Changes in liver weight* and liver protein content* in response to feeding BCKA or AA.

\begin{tabular}{lcc}
\hline Dietary treatment & $\begin{array}{c}\text { Liver weight } \\
(\mathrm{g})\end{array}$ & $\begin{array}{l}\text { Protein } \\
(\mathrm{g} / \text { liver })\end{array}$ \\
\hline Standard diet & $6.79 \pm 0.59$ & $1.37 \pm 0.09$ \\
BCKA & $5.73 \pm 0.56$ & $0.96 \pm 0.12$ \\
AA & $5.98 \pm 0.66$ & $0.97 \pm 0.07$ \\
\hline
\end{tabular}

$*$ Values are means $\pm \mathrm{SD}, n=6$.

Table 4. Leucine concentration* in plasma and liver of rats fed BCKA or AA.

\begin{tabular}{lcrr}
\hline & Standard diet & BCKA & \multicolumn{1}{c}{ AA } \\
\hline Plasma $(\mu \mathrm{M})$ & $134 \pm 7$ & $78 \pm 2$ & $66 \pm 2$ \\
Liver & $161 \pm 9$ & $169 \pm 7$ \\
$\left(\mathrm{nmol} \times \mathrm{g}^{-1}\right)$ & $250 \pm 6$ & & \\
\hline
\end{tabular}

*Values are means \pm SEM, $n=11-20$.

Vol. 30, No. 2, 1984 
Table 5. Effect of dietary treatment on the specific radioactivity of leucine in plasma, liver amino acid pool and liver proteins.*

\begin{tabular}{lccc}
\hline & & $\begin{array}{c}\text { Dietary treatment } \\
\text { BCKA }\end{array}$ & AA \\
$\left(\mathrm{dpm} \times 10^{-3} \times \mu \mathrm{mol}^{-1}\right)$ & \\
\hline Standard diet & $226 \pm 17^{\mathrm{a}, \mathrm{b}}$ & $316 \pm 15^{\mathrm{a}}$ & $331 \pm 15^{\mathrm{b}}$ \\
$\begin{array}{c}\text { Amino acid pool } \\
\text { of the liver }\end{array}$ & $114 \pm 7^{\mathrm{c}}$ & $199 \pm 16^{\mathrm{c}, \mathrm{d}}$ & $129 \pm 12^{\mathrm{d}}$ \\
Liver protein & $2.41 \pm 0.09$ & $3.00 \pm 0.34^{\mathrm{e}}$ & $1.82 \pm 0.25^{\mathrm{e}}$ \\
\hline
\end{tabular}

*Values are means $\left(\mathrm{dpm} \times 10^{-3} \times \mu \mathrm{mol}^{-1}\right) \pm \mathrm{SEM}, n=5$. Means having common superscript letters are significantly different $(p<0.05)$.

Table 6. Effect of dietary treatment on incorporation of $\left[1-{ }^{14} \mathrm{C}\right]$ leucine and $\left[1-{ }^{14} \mathrm{C}\right] \alpha-$ ketoisocaproate into rat kidney and heart proteins.*

\begin{tabular}{cccc}
\hline $\begin{array}{c}\text { Compound } \\
\text { injected }\end{array}$ & Standard diet & $\begin{array}{c}\text { BCKA } \\
(\% \text { of injected dose } / \text { organ })\end{array}$ & AA \\
\hline & \multicolumn{3}{c}{ Kidney } \\
{$\left[1-{ }^{14} \mathrm{C}\right]$ Leu } & $0.588 \pm 0.049$ & $0.526 \pm 0.046$ & $0.515 \pm 0.062$ \\
{$\left[1-{ }^{14} \mathrm{C}\right] \alpha-$ KIC } & $0.346 \pm 0.016$ & $0.419 \pm 0.031$ & $0.475 \pm 0.053$ \\
& & Heart & \\
{$\left[1-{ }^{14} \mathrm{C}\right]$ Leu } & $0.012 \pm 0.001$ & $0.015 \pm 0.001$ & $0.014 \pm 0.002$ \\
{$\left[1-{ }^{14} \mathrm{C}\right] \alpha-$ KIC } & $0.010 \pm 0.001^{\mathrm{a}, \mathrm{b}}$ & $0.019 \pm 0.001^{\mathrm{a}}$ & $0.020 \pm 0.002^{\mathrm{b}}$ \\
\hline
\end{tabular}

* Values are expressed as means of per cent of the injected dose per whole organ \pm SEM, $n=5$. Means having common superscript letters are significantly different $(p<0.05)$

Differences between feeding the standard and the BCKA-diet consist in the elevated specific radioactivity of the amino acid pool of livers from rats fed on the BCKAdiet.

Besides the liver, incorporation rates were also measured in brain (Table 2) heart and kidney proteins (Table 6).

Surprisingly, rates of incorporation into brain proteins were higher after the injection of BCKA than after the injection of BCAA, whereas leucine and valine were incorporated to the same extent. The rates of $\left[1-{ }^{14} \mathrm{C}\right]$ leucine incorporation into kidney and heart proteins are shown in Table 6. Feeding the experimental diets does not lead to decreased leucine incorporation rates in either tissue. Not only in brain but also in kidney and heart proteins, rates of incorporation of radioactivity from $\alpha$ KIC are similar to those from leucine. 


\section{DISCUSSION}

The present paper clearly shows that dependent on the organ studied and on the diet applied, BCKA differ from BCAA as potential protein precursors.

Table 2 demonstrates that under standard dietary conditions incorporation into liver proteins after the injection of leucine is 1.5 times higher than after the injection of $\alpha$-ketoisocaproate. The difference in incorporation rates might be explained by the fact that in liver the activity of the branched-chain $\alpha$-ketoacid dehydrogenase [EC 1.2.4.4] for exceeds that of the branched-chain amino acid transaminase [EC 2.6.1.6] (12) so that transamination of $\alpha$-KIC is low compared to oxidative decarboxylation.

Of all precursors tested, injection of $\alpha$-ketoisovalerate ( $\alpha$-KIV) yielded the lowest incorporation rates in liver proteins. These data are in good agreement with experiments carried out in isolated liver cells in which transamination rates of $\alpha$ KIV were much smaller than those of $\alpha$-KIC (16).

The high $K_{\mathrm{m}}$ value of the branched-chain amino acid transaminase for valine, which is $5-10$ times higher than for leucine (17), may account for the low values.

Since BCKA have been proposed as dietary supplements to protein-deficient diets for patients with renal and hepatic insufficiency, we thought it of interest to investigate the influence of similar, yet more drastic, dietary conditions on rates of incorporation of BCAA into different tissue proteins. The BCKA-diet was enriched with high amounts of BCKA in order to make metabolic changes which might be induced by dietary BCKA become more obvious. Similar growth rates were obtained when feeding either experimental diet (Table 1).

Intake of the AA-diet led to a decrease of leucine and valine incorporation into liver proteins, which very likely reflects a reduced protein synthesis due to dietary nitrogen restriction. Quartey-Papafio et al.(18) reported a $25 \%$ decline in liver protein synthesis in response to feeding a diet containing $8 \%$ protein. In contrast to standard dietary conditions, differences between rates of incorporation of radioactivity from BCAA and their corresponding $\alpha$-ketoanalogues into liver proteins were not observed after application of the AA-diet (Table 2). This might be explained by the fact that under dietary nitrogen restriction the hepatic branched-chain $\alpha$ ketoacid dehydrogenase activity decreases whereas the activity of the branchedchain amino acid transaminase remains unchanged (12), so that once ketoacids have been taken up by the liver, they are transaminated rather than decarboxylated. Presumably the uptake of $\alpha$-ketoacids is limited, otherwise one would expect an increased conversion of $\alpha$-ketoacids to amino acids due to an increased availability of $\alpha$-ketoacids for transamination.

Surprisingly, despite similar liver weights and hepatic protein content, rates of incorporation of leucine and valine into liver proteins of BCKA-fed rats were higher than those of the AA-fed rats (Table 2).

In order to investigate the difference in incorporation rates between the two experimental groups, the specific radioactivity of leucine was determined in plasma, 
hepatic amino acid pool and liver protein (Table 5). Due to the low plasma leucine concentration in both experimental groups (Table 4), injection of leucine resulted in an increase in specific activity (Table 5).

Although leucine concentrations in rat liver were equally decreased in both experimental groups (Table 4), injection of leucine led to higher values of specific radioactivity in the amino acid pool of the BCKA-group than of the AA-group.

One could speculate that during the intake of a leucine-free diet (BCKA-diet) the transport system of leucine had undergone changes favouring an increased uptake of leucine. Changes in amino acid transport due to dietary factors have been described previously $(19,20)$. Dividing the specific radioactivity of leucine in liver protein by that determined in the amino acid pool, it follows that hepatic protein synthesis is reduced by approximately $30 \%$ in both experimental groups. Data derived from incorporation rates after injection of $\left[U-{ }^{14} \mathrm{C}\right]$ lysine are in good agreement with the above-mentioned results (Table 5). $\left[U-{ }^{14} \mathrm{C}\right]$ Lysine was chosen as the tracer amino acid since one would not expect lysine to be transported by a system that also transports leucine (20).

These results indicate that although feeding the BCKA-diet leads to increased rates of leucine $(5.79 \%)$ and presumably valine $(4.26 \%)$ incorporation into liver proteins (Table 2), there is no simultaneous stimulation of protein synthesis.

In heart and kidney, rates of incorporation of radioactivity from BCAA were not higher than from BCKA (Table 6) which might be due to high branched-chain amino acid transaminase activities in both organs (17).

In contrast to rates of incorporation of amino acid into liver proteins, no changes in incorporation rates into kidney, brain and heart proteins were observed after dietary restriction. In these tissues, protein synthesis is very low compared to liver and does not seem to be affected by dietary manipulation. Other authors have shown that despite drastic protein deprivation the brain seems fully capable of maintaining normal rates of protein synthesis (21).

Presenting the isotope data in terms of ratio of incorporation from ketoacids divided by incorporation from amino acids, the ratio exceeds unity in brain proteins (Table 2). Possibly uptake of BCKA into brain is higher than uptake of BCAA, so that considering the high transamination capacity of rat brain $(12,17)$, availability of BCAA for protein synthesis might increase.

Results obtained from rats fed on the standard and the BCKA-diet show that in liver where BCKA are predominantly decarboxylated, incorporation rates of radioactivity from BCKA are lower than those from BCAA. In tissues in which the activity of the branched-chain amino acid transaminase is higher than the branchedchain $\alpha$-ketoacid dehydrogenase activity, incorporation of BCKA equals or even exceeds that of BCAA. These data and the fact that feeding diets low in nitrogen does not diminish the rates of incorporation of BCKA suggest a potential role of $\mathrm{BCKA}$ as protein precursors. 
We are grateful to Mrs. Röschlau for her excellent technical assistance and to Dr. Prestele for the statistical counselling.

\section{REFERENCES}

1) Richards, P. (1972): Nutritional potential of nitrogen recycling in man. Am. J. Clin. Nutr., 25, 615-625.

2) Chow, K. W., and Walser, M. (1975): Effects of substitution of methionine, leucine, phenylalanine or valine by their $\alpha$-hydroxy analogs in the diet of rats. J. Nutr., 105, 372378.

3) Chow, K. W., and Walser, M. (1974): Substitution of five essential amino acids by their alpha-keto-analogues in the diet of rats. J. Nutr., 104, 1208-1214.

4) Chow, K. W., and Walser, M. (1975): Effect of nitrogen restriction on the utilization of $\alpha$-ketoisovalerate for growth in the weanling rat. J. Nutr., 105, 119-121.

5) Gaby, A. R., and Chawla, R. K. (1976): Efficiency of phenylpyruvic and phenyllactic acids as substitutes for phenylalanine in the diet of the growing rat. J. Nutr., 106, 158168.

6) Chawla, R. K., and Rudman, D. (1974): Utilization of $\alpha$-keto and $\alpha$-hydroxy analogues of valine by the growing rat. J. Clin. Invest., 54, 271-277.

7) Chawla, R. K., Stackhouse, W. J., and Wadsworth, A. D. (1975): Efficiency of $\alpha$ ketoisocaproic acid as a substitute for leucine in the diet of the growing rat. J. Nutr., 105, 798-803.

8) Walser, M., Coulter, A. W., Dighe, S., and Crantz, F. R. (1973): The effect of ketoanalogues of essential amino acids in severe chronic uremia. J. Clin. Invest., 52, 678690.

9) Maddrey, W. C., Weber, F. L., Coulter, A. W., Chura, C. M., Chapanis, N. P., and Walser, M. (1976): Effects of keto-analogues of essential amino acids in portalsystemic encephalopathy. Gastroenterology, 71, 190-195.

10) Batshaw, M., Brusilow, S., and Walser, M. (1975): Treatment of carbamoyl phosphate synthase deficiency with keto-analogues of essential amino acids. New Engl. J. Med., 292, 1085-1090.

11) Rogers, Q. R., and Harper, A. E. (1965): Amino acid diets and maximal growth in the rat. J. Nutr., 87, 267-273.

12) Hauschildt, S., and Brand, K. (1980): Effects of branched-chain $\alpha$-ketoacids on enzymes involved in branched-chain $\alpha$-ketoacid metabolism in rat tissues. J. Nutr., 110, 17091716.

13) Meister, A. (1952): Enzymatic preparation of $\alpha$-keto acids. J. Biol. Chem., 197, 309-317.

14) Bensadoun, A., and Weinstein, D. (1976): Assay of proteins in the presence of interfering materials. Anal. Biochem., 70, 241-250.

15) Scheffé, H. (1972): In Statistische Auswertungsmethoden, ed. by Sachs, L., Springer Verlag, Heidelberg, Berlin, New Y̌ork, pp. 391-411.

16) Brand, K. (1981): Metabolism of $\alpha$-keto acid analogues of leucine, valine and phenylalanine in extrahepatic and hepatic tissues, in Metabolism and Clinical Implications of Branched Chain Amino and Ketoacids, ed. by Walser, M. and Williamson, J. R., Elsevier North-Holland, pp. 135-142.

17) Ichihara, A., Noda, C., and Tanaka, K. (1981): Oxidation of branched chain amino acids with special reference to their transaminase, in Metabolism and Clinical Implications of Branched Chain Amino and Ketoacids, ed. by Walser, M. and Williamson, J. R., Elsevier North-Holland, pp. 227-231. 
18) Quartey-Papafio, P., Garlick, P. J., and Pain, V. M. (1980): Effect of dietary protein on liver protein synthesis. Biochem. Soc. Trans., 8, 357.

19) Fafournoux, P., Rémésy, C., and Demigné, C. (1982): Stimulation of amino acid transport into liver cells from rats adapted to a high protein diet. Biochem. J., 206, $13-18$.

20) Guidotti, G., Borghetti, A., and Gazzda, G. (1978): The regulation of amino acid transport in animal cells. Biochim. Biophys. Acta, 515, 329-366.

21) Freedman, L. S., and Samuels, S. (1980): Sparing of the brain in neonatal undernutrition: Amino acid transport and incorporation into brain and muscle. Science, 207, 902-904. 